
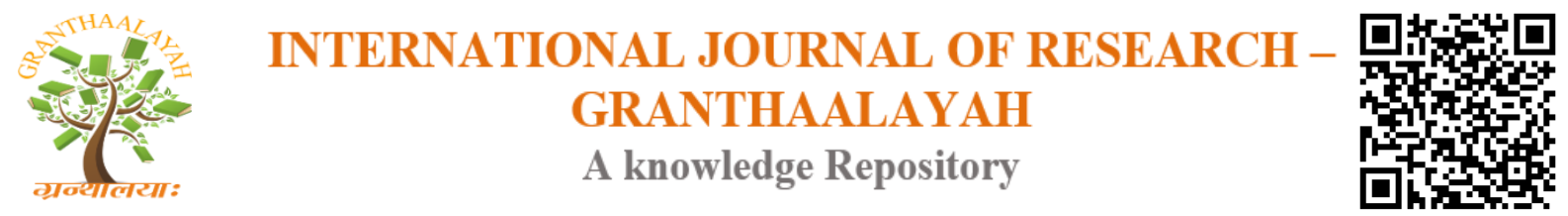

Science

\title{
RISK FACTORS FOR MATERNAL MORTALITY IN KHARTOUM STATE PUBLIC HOSPITALS, 2015
}

\author{
Dr.Fatima Alshikh Mohammed ${ }^{* 1}$, Dr.Adam Dawria ${ }^{2}$, Dr.Ali Mohieldin ${ }^{3}$, Amana Ahmed \\ Imam ${ }^{4}$, Prof Abdel Gaffar Ali Adam ${ }^{5}$ \\ ${ }^{* 1}$ PhD, Senior Lecturer at King Khalid University, College of Applied Medical Science, \\ Departments of Public Health \\ ${ }^{2}$ Assistant Professor PhD at King Khalid University College of Applied Medical Science Public \\ Health Department. WHO Independent Consultant \\ ${ }^{3,4}$ Associate Professor PhD at King Khalid University College of Applied Medical Science \\ Public Health Department \\ ${ }^{5}$ Ministry of health - health science academic -Sudan
}

\begin{abstract}
Maternal mortality is considered one of the major global health concerns especially in developing countries. The aim of this study is to explore the risk factors for maternal mortality in Khartoum State public hospitals, .A descriptive prospective hospital-based study was used. 120 maternal deaths were studied during 12 months, verbal autopsy questionnaire was adopted. Results: Odd ratio was used to assess the risk factors of maternal mortality and it was found that attended antenatal care $\mathrm{OR}=2.898)$, vaccinated against tetanus $(\mathrm{OR}=3.859)$, delayed for seeking health care $(\mathrm{OR}=8.406)$, delay reaching hospitals $(\mathrm{OR}=1.85)$, Delayed in receiving care $(\mathrm{OR}=1.6)$ were associated with mother residence too far from clinics.

The study concluded that low socio-economic status as well as rural and low education level of women was the major contributing factors for high maternal mortality and community mobilization, Political commitment to decreasing maternal mortality.
\end{abstract}

Keywords: Khartoum; Maternal Mortality; Public Hospitals.

Cite This Article: Dr.Fatima Alshikh Mohammed, Dr.Adam Dawria, Dr.Ali Mohieldin, Amana Ahmed Imam, and Prof Abdel Gaffar Ali Adam. (2018). "RISK FACTORS FOR MATERNAL MORTALITY IN KHARTOUM STATE PUBLIC HOSPITALS, 2015." International Journal of Research - Granthaalayah, 6(3), 246-251. 10.29121/granthaalayah.v6.i3.2018.1520.

\section{Introduction}

The WHO defines maternal death as the "Maternal death is the death of a woman while pregnant or within 42 days of termination of pregnancy, irrespective of the duration and site of the pregnancy, from any cause related to or aggravated by the pregnancy or its management but not from accidental or incidental causes, (1) 
Improving maternal health is one of the eight Millennium Development Goals adopted by the international community at the United Nations Millennium Summit in 2000(2)

Women die from a wide range of complications in pregnancy, childbirth or the postpartum period. Most of these complications develop because of their pregnant status. The four major killers are: severe bleeding (mostly postpartum bleeding), infections (also mostly soon after delivery), hypertensive disorders in pregnancy (eclampsia) and obstructed labor. Among the indirect causes (20\%) of maternal death are diseases that complicate pregnancy or are aggravated by pregnancy, such as malaria, anemia and HIV, (3). Women also die because of poor health at conception and a lack of adequate care needed for the healthy outcome of the pregnancy for themselves and their babies, (4). Maternal mortality in Sudan is still high which increases the challenges to keep pace with the MDG target with 2015, (5). Because there is no accurate vital registration system in Sudan, maternal mortality estimates in Sudan were based on indirect and direct sisterhood estimates as in the demographic surveys conducted in the past four decades. Estimated risk factors of maternal mortality over time are critical in that they help in planning of reproductive health programs to reduce mortality. The prospective descriptive studies about risks factors for maternal mortality in Khartoum state hospitals are rare.

\section{Materials and Methods}

This is a prospective descriptive hospital-based study of all maternal death at public hospitals in Khartoum state. Total coverage of all maternal death occurred in maternity department from June 2014to June 2015 in Khartoum public hospitals which were 120 deaths. Information of deceased was collected immediately from relatives, by used Adapted verbal autopsy questionnaire 2012 (Standard World Health Organization) after trained data collectors. The questionnaire including socio-demographic, causes, antenatal visit, health service used for the final illness, cost of illness.

The data was analyzed by using SPSS version 20, the odds ratio and binary logistic regression was used to assess the risk factors. The qualitative data were analyzed manually. All data about risk factors were categorical first, coding to 0,1 and analyzed using contingency table and chisquare tests to find risk factor associated with deceased women. An odds ratio (OR) is used to determine whether a particular exposure is a risk factor for maternal mortality. Odds ratio are most commonly used in case-control studies, however they can also be used in cross-sectional and cohort study designs as well with some modifications and/or assumptions),(6). The Odds ratios (ORs) 95\% confidence intervals and p-values are reported for three group of risk factors (residence place, socio-economic status, educational level association with health services, illness risk factors)

\section{Results}

Table 1: Association between deceased residence and health service and illness risk factors in Khartoum state public hospitals during study period

\begin{tabular}{|l|l|l|l|l|l|l|}
\hline Risk factors & Answers & \% Urban & $\begin{array}{l}\text { \% } \\
\text { rural }\end{array}$ & $\begin{array}{l}\text { Odd } \\
\text { ratio }\end{array}$ & $\begin{array}{l}\text { Confidence } \\
\text { interval }\end{array}$ & P value \\
\hline Antenatal care visit & Yes & $75.30 \%$ & $24.70 \%$ & 2.898 & $(1.29-6.48)$ & 008 \\
\hline
\end{tabular}




\begin{tabular}{|c|c|c|c|c|c|c|}
\hline & $\mathrm{NO}$ & $\% 51 \%$ & 48.7 & & & \\
\hline \multirow{2}{*}{$\begin{array}{l}\text { Vaccinated against } \\
\text { tetanus }\end{array}$} & Yes & $80.20 \%$ & $19.80 \%$ & 3.859 & $(1.67-8.87)$ & 001 \\
\hline & No & $51.30 \%$ & $48.70 \%$ & & & \\
\hline \multirow{2}{*}{$\begin{array}{l}\text { Delay in reaching near } \\
\text { hospitals }\end{array}$} & Yes & $16 \%$ & $84 \%$ & 1.85 & $(.034-.209)$ & .000 \\
\hline & No & $69.20 \%$ & $30.80 \%$ & & & \\
\hline \multirow{2}{*}{$\begin{array}{l}\text { Delayed for seeking } \\
\text { health care }\end{array}$} & No delay & $71.60 \%$ & $23.10 \%$ & 8.406 & $(3.46-20.4)$ & .000 \\
\hline & Delay & $28.40 \%$ & $76.90 \%$ & & & \\
\hline \multirow{2}{*}{$\begin{array}{l}\text { Delayed in receiving } \\
\text { care }\end{array}$} & Yes & $27.20 \%$ & $69.20 \%$ & 1.6 & $(.272-.383)$ & .000 \\
\hline & $\mathrm{NO}$ & $72.80 \%$ & $30.80 \%$ & & & \\
\hline \multirow[t]{2}{*}{ Malaria } & Yes & $11.10 \%$ & $88.90 \%$ & 1 & $(.315-3.79)$ & .888 \\
\hline & No & $10.30 \%$ & $89.70 \%$ & & & \\
\hline \multirow[t]{2}{*}{ High blood pressure } & Yes & $18.50 \%$ & $81.50 \%$ & 1 & $(. .24-6.4)$ &. .246 \\
\hline & No & $10.30 \%$ & 89.9 & & & \\
\hline \multirow[t]{2}{*}{ Anemia } & Yes & $4.90 \%$ & $95.10 \%$ & 0.455 & $(.107-1.923)$ & .274 \\
\hline & No & $10.30 \%$ & $89.90 \%$ & & & \\
\hline
\end{tabular}

Table 2: Association between deceased educational status and health services, illness risk factors in Khartoum state public hospitals during study period

\begin{tabular}{|c|c|c|c|c|c|c|}
\hline Risk factors & Answers & $\begin{array}{l}\text { Secondary } \\
\%\end{array}$ & $\begin{array}{l}\text { No and } \\
\text { primary } \%\end{array}$ & $\begin{array}{l}\text { Odd } \\
\text { ratio }\end{array}$ & $\begin{array}{l}\text { Confidence } \\
\text { interval CI }\end{array}$ & $\begin{array}{l}\mathbf{P} \\
\text { value }\end{array}$ \\
\hline \multirow{2}{*}{$\begin{array}{l}\text { Antenatal care } \\
\text { visit }\end{array}$} & Yes & $67.70 \%$ & $40 \%$ & 4.929 & $(2.047-11.86)$ & 0 \\
\hline & $\mathrm{NO}$ & $23.30 \%$ & $60 \%$ & & & \\
\hline \multirow{2}{*}{$\begin{array}{l}\text { Vaccinated } \\
\text { against tetanus }\end{array}$} & Yes & $81.10 \%$ & $40 \%$ & 6.441 & $(2.616-15.86)$ & 0 \\
\hline & No & $18.90 \%$ & $60 \%$ & & & \\
\hline \multirow{2}{*}{$\begin{array}{l}\text { Delay in reaching } \\
\text { near hospitals }\end{array}$} & Yes & $30 \%$ & $40 \%$ & 0.643 & $.272-1.517$ & 0.311 \\
\hline & No & $70 \%$ & $60 \%$ & & & \\
\hline \multirow{2}{*}{$\begin{array}{l}\text { Delayed for } \\
\text { Seeking health } \\
\text { care }\end{array}$} & No delay & $61.10 \%$ & $40 \%$ & 2.357 & $(1.013-5.484)$ & .044 \\
\hline & Delay & $38.90 \%$ & $60 \%$ & & & \\
\hline \multirow{2}{*}{$\begin{array}{l}\text { Delayed in } \\
\text { receiving care }\end{array}$} & Yes & $36.70 \%$ & $53.30 \%$ & 0.507 & $(.220-1.168)$ & 0.108 \\
\hline & No & $73.30 \%$ & $46.70 \%$ & & & \\
\hline \multirow[t]{2}{*}{ Malaria } & Yes & $8.90 \%$ & $16.70 \%$ & 0.488 &.$(.146-.1 .62)$ & 0.235 \\
\hline & $\mathrm{No}$ & $91.10 \%$ & $83.30 \%$ & & & \\
\hline \multirow{2}{*}{$\begin{array}{l}\text { High blood } \\
\text { pressure }\end{array}$} & Yes & 16.7 & $13.30 \%$ & 1 & $(.396-4.272)$ & 0.665 \\
\hline & No & 83.3 & $86.70 \%$ & & & \\
\hline
\end{tabular}




\begin{tabular}{|l|l|l|l|l|l|l|}
\hline Anemia & Yes & $6.70 \%$ & $6.70 \%$ & 1 & $(.191-5.241)$ & 1 \\
\hline & No & $93.30 \%$ & $93.30 \%$ & & & \\
\hline
\end{tabular}

Table 3: Association between deceased socio- economical status versus health service and illness risk factors for deceased in Khartoum state public hospitals during study period

\begin{tabular}{|c|c|c|c|c|c|c|}
\hline Risk factors & Answers & $\begin{array}{l}\text { Lower } \\
\%\end{array}$ & Higher & $\begin{array}{l}\text { Odd } \\
\text { ratio }\end{array}$ & $\begin{array}{l}\text { Confidence } \\
\text { interval CI }\end{array}$ & $\begin{array}{l}\mathbf{P} \\
\text { value }\end{array}$ \\
\hline \multirow[t]{2}{*}{ Antenatal care visit } & Yes & $66.40 \%$ & $100 \%$ & 0.641 & $(.294-.1 .593)$ & 0.261 \\
\hline & $\mathrm{NO}$ & $33.60 \%$ & 0 & & & \\
\hline \multirow{2}{*}{$\begin{array}{l}\text { Vaccinated against } \\
\text { tetanus }\end{array}$} & Yes & $76.30 \%$ & $74.50 \%$ & 0.715 & $(.322-.1 .591)$ & 0.411 \\
\hline & No & $32.70 \%$ & $25.50 \%$ & & & \\
\hline \multirow{2}{*}{$\begin{array}{l}\text { Delay in reaching } \\
\text { near hospitals }\end{array}$} & Yes & $41.50 \%$ & $21.80 \%$ & 3.546 & $(1.135-.5 .712)$ & 0.022 \\
\hline & $\mathrm{No}$ & $58.50 \%$ & $78.20 \%$ & & & \\
\hline \multirow{2}{*}{$\begin{array}{l}\text { Delayed seeking } \\
\text { health care }\end{array}$} & No delay & $61.50 \%$ & $23.60 \%$ & 5.167 & $(2.328-11.480)$ & 0 \\
\hline & Delay & $38.50 \%$ & $76.40 \%$ & & & \\
\hline \multirow{2}{*}{$\begin{array}{l}\text { Delayed in } \\
\text { receiving care }\end{array}$} & Yes & $11.30 \%$ & $10.40 \%$ & 1 & $(.345-3.474)$ & 0.879 \\
\hline & $\mathrm{No}$ & $88.70 \%$ & $86.60 \%$ & & & \\
\hline \multirow[t]{2}{*}{ Malaria } & Yes & 7.7 & $14.50 \%$ & 0.49 & $(.271-.947)$ & 0.229 \\
\hline & No & 92.3 & $85.50 \%$ & & & \\
\hline \multirow[t]{2}{*}{ High blood pressure } & Yes & 13.8 & $18.20 \%$ & 0.723 & $(.271-.1 .931)$ & 0.517 \\
\hline & No & 86.2 & $81.80 \%$ & & & \\
\hline \multirow[t]{2}{*}{ Anemia } & Yes & 6.2 & $7.30 \%$ & 0.836 & $(.199-.3 .519)$ & 0.807 \\
\hline & $\mathrm{No}$ & 93.8 & $92.70 \%$ & & & \\
\hline
\end{tabular}

\section{Discussions}

The chi square and odd ratio revealed all health services such as antenatal care visit $(\mathrm{OR}=2.898$ , $\mathrm{P}$ value $=.008)$, vaccinated against tetanus $(\mathrm{OR}=3.859, \mathrm{P}$ value $=.001)$, delayed for seeking health care $(\mathrm{OR}=8.406, \mathrm{P}$ value $=.000)$, Delay in reaching hospitals $(\mathrm{OR}=1.85, \mathrm{P}$ value $=.000)$, Delayed in receiving care $(\mathrm{OR}=1.6, \mathrm{P}$ value $=.000)$ ) were significantly associated with deceased residence and posed higher risk to maternal deaths. Other illness risk factor associated with deceased in resident place such as malaria $(\mathrm{OR}=1, \mathrm{P}$ value $=.888)$, anemia, $(\mathrm{OR}=$ $.455, \mathrm{P}$ value $=.274)$, high blood pressure $(\mathrm{OR}=1.9, \mathrm{P}$ value $=.246)$ were not significant and lower risk to maternal death.

Comparing this with the study conducted in Sudan 2010, about factors contributing to maternal mortality, found delays factors and accessibility factors, antenatal care visit were risk factors for maternal death. Another study in Kenya about risk factors showed antenatal care visit factor is significantly increased risk to maternal death, (7). It was observed that women in rural areas wireless likely to use and obtain maternal health services and these showed increased risk to die, than those in urban area. 
It was found that there is relationship between educational status of deceased versus health services and illness risk factors. The significant and increased odds are found in three factors, Antenatal care visit $(\mathrm{OR}=4.929 \mathrm{P}$ value $=.000)$, vaccinated against tetanus $(\mathrm{OR}=6.441 \mathrm{P}$ value $=.000)$, delayed for seeking health care $(\mathrm{OR}=2.357 \mathrm{P}$ value $=.044)$. Other factors such as, those who Delayed in receiving care $(\mathrm{OR}=.643 \mathrm{P}$ value $=.311)$, malaria $(\mathrm{OR}=$ $.488 \mathrm{P}$ value $=.235)$ high blood pressures $(\mathrm{OR}=1.3 \mathrm{P}$ value $=.665)$, anemia $(\mathrm{OR}=1.00$ value $=1.000)$ are not significant. Women with no education and women with primary education were found more likely to die from these risk factors than women with secondary education and above Delay in seeking health care was related to educational status because women not educated or poorly educated did not recognize illness and danger signs to seek health care when needed. In addition, antenatal care and vaccination against tetanus are at higher risk to maternal deaths in association with the maternal education, This was in line with other findings which revealed an association between Antenatal care visit use and the woman's education level and the association between maternal mortality and illiteracy was found to be significant in two studies in Sudan , $\{8,9)$.

Also our study found delayed for seeking health care $(\mathrm{OR}=5.16, \mathrm{P}$ value $=.000)$ Delay in reaching near hospitals $(\mathrm{OR}=3.4, \mathrm{P}$ value $=.022)$, are significant association and high risks to maternal death . The study conducted in Sudan 2013, showed that transportation cost in Khartoum State was one of the factors, having negative impacts on seeking facility based delivery, (8)

\section{Conclusions and Recommendations}

All health services risk factors were found significant effect on deceased residence and increased risk to maternal mortality .Delay in seeking health care, antenatal care visit, vaccinated against tetanus were found significant risk to maternal death in association with educational level.

Delayed for seeking health care and delay in reaching near hospitals were significant association to maternal death in relationship with the socio economic status of the deceased.

Malaria, high blood pressures, anemia were not significant and have lower risks to maternal deaths.

The main recommendations of our study are political commitment to decreasing maternal mortality is vital to the success of programs. Strengthen community mobilization to support utilization of maternal health services. Women empowerment program and income generation project are to be established to solve non-health service problems, like poverty, female education, and socio-economic status., .

\section{Acknowledgements}

Deep thanks passed to the hospitals administration regarding the continues collaborations were offered. Special thanks to the data collectors and our thanks to my colleagues in the department of public health in king Khalid University for their assistant in reviewing our works. 


\section{References}

[1] WHO, Health statistic and health information Geneva,2013 (onlineaccess1/2013) http://www.who.int/healthinfo/statistics/indmaternalmortality/en/

[2] CDC, Maternal health epidemiology , Reproductive health epidemiology series module 2 JUNE 2003 (online access 2013) www.cdc.gov/reproductivehealth/.../pdfs/epi_module_2_04_tag508.pd

[3] WHO, MDG5 :improve maternal health topic 2013 (online 2013 http://www.who.int/topics/millennium

[4] CDC, Maternal health epidemiology , Reproductive health epidemiology series module 2 JUNE 2003 (online access 2013) www.cdc.gov/reproductivehealth/.../pdfs/epi_module_2_04_tag508.pd.

[5] WHO, maternal mortality fact sheetmaternal mortality media center2014(onlineaccessMay/2014) http://www.who.int/mediacentre/factsheets (online access 1/2014)

[6] Szumilas M. Explaining Odds Ratios. Journal of the Canadian Academy of Child and Adolescent Psychiatry. 2010; 19(3):227-229. http://www.ncbi.nlm.nih.gov/pmc/articles/PMC2938757/

[7] Faith Yego, Risk factors for maternal mortality in a Tertiary Hospital in Kenya, Department of Health Policy and Management, Moi University, Eldoret 30100, Kenya . BMC Pregnancy andChildbirth 2014, 14:38 accessed from http://www.biomedcentral.com/1471-2393/14/38)

[8] Abdullah A Mohammed, Mahgoub H Elnour, Eltayeb E Mohammed, Samah A Ahmed, and Ahmed I Abdelfattah community-based study using Reproductive age mortality survey over a three-year period 9 Sudan, (2004-2006) http://www.ncbi.nlm.nih.gov/pmc/articles/PMC3260097/

[9] SHAZA AHMED SIDAHMED, Factors contributing to maternal mortality in Sudan August 2013 49th49th International Course in Health DevelopmentSeptember2012-September2013 from accessed 2014. http://www.sharepdf.com/834ceffd0bed4134b6ff0dc5d101ec89/12\%20Augus

*Corresponding author.

E-mail address: fatimaelhadi1984@gmail.com 